\title{
The molecular basis of the non-thyroidal illness syndrome
}

\author{
Emmely M de Vries, Eric Fliers and Anita Boelen
}

Department of Endocrinology and Metabolism, Academic Medical Center, University of Amsterdam, Meibergdreef 9, 1105 AZ Amsterdam, The Netherlands

Correspondence

should be addressed

to A Boelen

Email

a.boelen@amc.uva.nl

\begin{abstract}
The 'sick euthyroid syndrome' or 'non-thyroidal illness syndrome' (NTIS) occurs in a large proportion of hospitalized patients and comprises a variety of alterations in the hypothalamus-pituitary-thyroid (HPT) axis that are observed during illness. One of the hallmarks of NTIS is decreased thyroid hormone (TH) serum concentrations, often viewed as an adaptive mechanism to save energy. Downregulation of hypophysiotropic TRH neurons in the paraventricular nucleus of the hypothalamus and of TSH production in the pituitary gland points to disturbed negative feedback regulation during illness. In addition to these alterations in the central component of the HPT axis, changes in TH metabolism occur in a variety of TH target tissues during NTIS, dependent on the timing, nature and severity of the illness. Cytokines, released during illness, are known to affect a variety of genes involved in TH metabolism and are therefore considered a major determinant of NTIS. The availability of in vivo and in vitro models for NTIS has elucidated part of the mechanisms involved in the sometimes paradoxical changes in the HPT axis and TH responsive tissues. However, the pathogenesis of NTIS is still incompletely understood. This review focusses on the molecular mechanisms involved in the tissue changes in TH metabolism and discusses the gaps that still require further research.
\end{abstract}
Key Words
- nonthyroidal illness
- thyroid hormone transporters
- thyroid hormone receptors
- deiodinases

Journal of Endocrinology (2015) 225, R67-R81

\section{Introduction}

Illness results in profound changes in thyroid hormone (TH) metabolism called the 'sick euthyroid syndrome' or 'nonthyroidal illness syndrome' (NTIS). NTIS is characterized by decreased serum triiodothyronine $\left(\mathrm{T}_{3}\right)$ and thyroxine $\left(\mathrm{T}_{4}\right)$ concentrations, increased serum reverse $\mathrm{T}_{3}\left(\mathrm{rT}_{3}\right)$ concentrations and unaltered or inappropriately low serum thyroid-stimulating hormone (TSH), indicating profoundly altered negative feedback in the pituitary and hypothalamus (Docter et al. 1993). The alterations in the central part of the hypothalamus-pituitary-thyroid (HPT) axis are combined with reduced production of $\mathrm{T}_{3}$ and impaired clearance of $\mathrm{rT}_{3}$ by the liver, and with specific changes in peripheral TH metabolism in major $\mathrm{T}_{3}$ target organs. Muscle and adipose tissue show additional and differential changes in TH metabolism. The role of the thyroid gland has been largely neglected with regard to illness induced alterations in TH metabolism for many years, but in vitro studies showed that genes involved in the production and release of $\mathrm{T}_{4}$ and $\mathrm{T}_{3}$ are severely affected by high concentrations of pro-inflammatory cytokines (Bartalena et al. 1998). In addition, acute inflammation in mice reduced thyroidal TSH-receptor expression preceded by an acute increase in interleukin 1 beta (IL1 $\beta$ ) expression (Boelen et al. 2004a). Thus, the

Published by Bioscientifica Ltd 
thyroid gland itself is clearly involved in the pathogenesis of NTIS. The ultimate effects of the observed changes in local TH metabolism on tissue function during illness are currently unknown. However, the common view is that while changes observed during the acute phase of illness are beneficial they may become deleterious during prolonged critical illness, making the stage and severity of illness a major determinant of NTIS.

Cytokines have been implicated in the development of NTIS for more than two decades. IL6 was found to be negatively correlated with serum $\mathrm{T}_{3}$ concentrations in hospitalized patients (Boelen et al. 1993). In mice, administration of bacterial endotoxin or lipopolysaccharide (LPS) results in an acute increase of serum IL6 and tumor necrosis factor alpha (TNF $\alpha$ ) concentrations (Boelen et al. 1995). A causal role for IL6 in the development of NTIS in mice was shown since IL6 knock out mice show a less pronounced drop in serum $\mathrm{T}_{3}$ during illness (Boelen et al. 1996). However, acute injection of cytokines failed to induce NTIS like features, except for interferon gamma (IFN $\gamma$ ) which reduces serum $\mathrm{T}_{3}$ and $\mathrm{T}_{4}$ (Boelen et al. 1995). Chronic infusions with IL1 and IL6 on the other hand mimick certain symptoms such as decreased serum $\mathrm{T}_{4}$ and $\mathrm{T}_{3}$ and decreased thyrotropinreleasing hormone (TRH) expression in the hypothalamus in mice (van Haasteren et al. 1994), while chronic IL1 $\beta$ infusions mimicks certain aspects of NTIS in the rat (Hermus et al. 1992).

Mechanisms involved in the pathogenesis of NTIS have predominantly been studied by using a variety of in vivo and in vitro models. Several NTIS rodent models have been described i.e. acute illness, induced by administration of a sublethal dose of LPS (Boelen et al. 2004a, Fekete et al. 2004); chronic inflammation, induced by injection of turpentine in the hind limb ultimately resulting in the formation of an abscess (Chopra et al. 1987, Boelen et al. 2006); bacterial sepsis, induced by inoculation of Streptococcus pneumoniae or i.p. injection with Escherichia coli (Knapp et al. 2003, Boelen et al. 2008) and prolonged critical illness in rabbits induced by burn injury (Weekers et al. 2002). The similarity between these models is the decrease in serum TH concentrations, although the time course, severity and inflammatory response are variable. The availability of transgenic mice provided the possibility to study the specific contribution of genes involved in $\mathrm{TH}$ metabolism in the context of NTIS. The role of specific molecular factors involved in the altered $\mathrm{TH}$ metabolism has been studied extensively in vitro by using a variety of cell lines that were stimulated with LPS or pro-inflammatory cytokines with and without specific inhibitors. In this review, we discuss changes in TH regulation and metabolism during NTIS, and the molecular mechanisms involved.

\section{IIIness induced alterations in hypothalamic TRH expression}

The combination of low serum $\mathrm{TH}$ and an inappropriately low TSH response suggests central down-regulation of the HPT axis. This is supported by the observation that TRH gene expression in the paraventricular nucleus (PVN) of the hypothalamus was decreased in post mortem hypothalamic tissue of patients who died after prolonged illness as compared with patients with acute cardiac arrest. Moreover, TRH mRNA expression in the PVN correlates positively with pre-mortem serum $\mathrm{TSH}_{\mathrm{H}}$ and $\mathrm{T}_{3}$ levels (Fliers et al. 1997). In addition, several animal studies show that hypothalamic TRH expression also decreases after acute inflammation (Kakucska et al. 1994), chronic inflammation (Boelen et al. 2006) and prolonged critical illness in rabbits (Mebis et al. 2009). However, the underlying mechanisms are incompletely understood. Local $\mathrm{T}_{3}$ bioavailability in the hypothalamus might play a role as $\mathrm{TR} \beta^{0 / 0}$ mice display an impaired illness induced TRH decrease and TR $\beta$ signalling is important for the feedback regulation of $\mathrm{T}_{3}$ on TRH neurons. However, the role of circulating $\mathrm{TH}$ is probably limited as alterations in the hypothalamus that are supposed to be involved in the illness induced TRH decrease precede the decrease in circulating $\mathrm{TH}$ levels (Fekete et al. 2005). A striking observation that has been linked to the illness induced TRH decrease is a marked increase in type 2 deiodinase (D2/Dio2) mRNA expression both in tanycytes, specialised cells lining the wall of the third ventricle (de Vries et al. $2014 a$ ) and in the hypothalamus of a variety of rodent and rabbit NTIS models (Boelen et al. 2004a, 2006, Fekete et al. 2004, Mebis et al. 2009). D2 is the main $T_{3}$ producing enzyme in the brain and involved in the regulation of local TH availability. In an in vitro coculture system, increased D2 expression in glial cells results in an increase of $\mathrm{T}_{3}$ responsive gene expression in cocultured neurons, indicating that increased $\mathrm{T}_{3}$ production by $\mathrm{D} 2$ in tanycytes could influence adjacent neurons in a paracrine fashion (Freitas et al. 2010). The observation that TR $\beta^{0 / 0}$ mice do not show a hypothalamic TRH decrease supports the role for local $\mathrm{T}_{3}$ in the suppression of TRH secretion (Boelen et al. 2009a). The mechanisms involved in the illness induced increase in Dio2 mRNA expression are discussed in the following section. In addition, both IL1 $\beta$ and corticosterone are known to affect Trh expression directly

Published by Bioscientifica Ltd 
and could also contribute to the TRH decrease upon inflammation (Kakucska et al. 1994, 1995). TRH is also decreased during starvation suggesting that part of the observed TRH decrease during illness might be a result of the diminished food intake associated with illness. However, in a mouse model for chronic inflammation, diminished food intake does not play a role in the observed Trh decrease (Boelen et al. 2006).

\section{Illness induced alterations in pituitary TSH $\beta$ expression}

One of the characteristics of NTIS is the absence of an appropriate TSH response in the face of low serum $\mathrm{T}_{4}$ and $\mathrm{T}_{3}$ concentrations. Low TSH serum concentrations and decreased Tsh $\beta$ mRNA expression in the pituitary have been described in a wide variety of animal models (Boelen et al. 2004a, 2006, Fekete et al. 2004, Mebis et al. 2009). The mechanism involved is still unclear although we showed that the illness induced decrease of $T s h \beta$ expression depends on functional thyroid hormone receptor (TR) signaling, since $\mathrm{TR} \beta^{0 / 0}$ mice show a blunted $T \operatorname{sh} \beta$ decrease upon LPS stimulation compared to their WT counterparts (Boelen et al. 2009a). The diminished food intake that is associated with chronic inflammation is only partly responsible for the observed $T s h \beta$ decrease (Boelen et al. 2006).

The pituitary expresses both D1/Dio1 and D2 (Alkemade et al. 2006). The $\mathrm{D} 2$ mediated conversion of $\mathrm{T}_{4}$ to $\mathrm{T}_{3}$ has been thought to be important for the feedback of TH on TSH, since D2 knock out mice show a disturbed negative feedback (Schneider et al. 2001). As the LPS induced suppression of TRH in the hypothalamic PVN is associated with an increase of Dio2 expression in the mediobasal hypothalamus (Boelen et al. 2004a, Fekete et al. 2004), it was speculated that the LPS induced decrease in $T s h \beta$ expression might also be dependent on increased D2 activity in the pituitary. Surprisingly, the response of Dio2 expression in the pituitary after LPS appeared to be dependent on the species, strain and type of illness studied; both increased and decreased Dio2 expression have been observed (Boelen et al. 2004a, 2006, 2009a, Fekete et al. 2004). Furthermore, administration of LPS to rats results in an increased pituitary D2 activity after 12 and $24 \mathrm{~h}$, which is dependent on the fall in $\mathrm{TH}$ concentrations, in contrast to the hypothalamic D2 increase (Fekete et al. 2005). Further studies using pituitary specific D2 knock out mice are necessary to investigate the exact role of D2 in the LPS induced alterations in TH metabolism in the pituitary.
In addition to Dio2, the expression of Dio1 in the pituitary is increased during inflammation (Boelen et al. $2004 a, 2009 a$ ). This change is mediated by the increase in cytokines during the acute phase response, since animals deficient for IL12 and IL18 do not show the LPS induced increase (Boelen et al. 2004b,c). If the D1 increase in the pituitary gland serves a purpose with regard to the $T \operatorname{sh} \beta$ decrease is unknown at present. Alternatively, the $T s h \beta$ decrease might be dependent on the changes in Dio2 expression in the mediobasal hypothalamus, which could affect the pituitary either via suppression in Trh expression or theoretically via an increase in $\mathrm{T}_{3}$ transported from the hypothalamus to the pituitary via the portal capillaries (Fekete \& Lechan 2007).

In vitro studies using primary cultures of pituitary cells show that cytokines have a pronounced effect on pituitary release of TSH $\beta$. Both IL1 $\beta$ and TNF $\alpha$ decrease basal TSH $\beta$ release independently of $T_{3}$ uptake and action in the pituitary cells (Harel et al. 1995, Wassen et al. 1996). Interestingly, acute energy deprivation has no effect on TSH $\beta$ release from pituitary cells in culture, consistent with the in vivo studies discussed above showing that the TSH $\beta$ decrease during chronic inflammation is only partly explained by decreased food intake (Boelen et al. 2006).

\section{The effect of cytokines on TH synthesis}

Several components of the TH synthesis pathway are downregulated by cytokines directly on the level of the thyrocyte, ultimately leading to decreased secretion of $\mathrm{T}_{4}$ and $\mathrm{T}_{3}$ (Bartalena et al. 1998).

Supraphysiological concentrations of the pro-inflammatory cytokines IL1 $\alpha$ and IL1 $\beta$ inhibit the TSH-induced thyroglobulin (Tg) mRNA expression and $\mathrm{Tg}$ release in human cultured thyrocytes via suppression of cAMP (Rasmussen et al. 1988, 1994, Yamashita et al. 1989). IL1 $\alpha$ and IL1 $\beta$ also decrease ${ }^{125}$ I incorporation and $\mathrm{T}_{4}$ and $\mathrm{T}_{3}$ secretion from human thyrocytes in the presence of TSH (Sato et al. 1990). Thyroid peroxidase (TPO) mRNA expression and protein content, important for the oxidation of iodide to iodine, is also directly affected by IL1 in human thyrocytes and rat thyroid FTRL-5 cells (Asakawa et al. 1996, Gerard et al. 2006). Moreover, IL1 $\beta$ impairs basal and TSH-stimulated uptake of iodide by the natrium/iodide symporter (NIS) in porcine thyroid follicles (Nolte et al. 1994). The role of IL6 is less well established: one study showed that IL6 inhibits the TSHand cAMP-induced increase in TPO mRNA expression and $\mathrm{T}_{3}$ secretion in thyrocytes obtained from Graves' disease patients (Tominaga et al. 1991), while IL6 has

Published by Bioscientifica Ltd. 
only a minor effect on cultured human thyroid cells (Rasmussen et al. 1991).

IFN $\gamma$ is a cytokine that is mainly involved in anti-viral and anti-bacterial responses and is produced by natural killer and T-cells. INF $\gamma$ has a variety of effects on human thyrocytes in culture; it inhibits TSH- induced TH and Tg secretion (Nagayama et al. 1987, Kung et al. 1992) as well as Tg mRNA expression (Sato et al. 1990), TSH-induced TPO expression (Ashizawa et al. 1989) and the TSH- and cAMPinduced upregulation of TSH receptors on the thyrocyte (Nishikawa et al. 1993). IFN $\gamma$ also inhibits the TSH-induced increase in NIS expression in rat FTRL-5 cells resulting in diminished iodide uptake (Ajjan et al. 1998). Interestingly, overexpression of IFN $\gamma$ in thyroid cells in a transgenic mouse leads to primary hypothyroidism mainly due to a big decrease in NIS mRNA and protein expression (Caturegli et al. 2000).

$\mathrm{TNF} \alpha$ plays an important role in the acute phase response and is known to inhibit the TSH-induced cAMP response and Tg production (Deuss et al. 1992) and release (Poth et al. 1991, Rasmussen et al. 1994) in cultured thyrocytes. TNF $\alpha$ also inhibits NIS expression in rat FTRL-5 cells (Ajjan et al. 1998).

Finally, cytokines are able to inhibit D1 expression and activity in the rat thyrocyte and FRTL-5 cells (Pekary et al. 1994, Hashimoto et al. 1995, Tang et al. 1995). Taken together, these studies clearly show that cytokines, either alone or synergistically, are able to downregulate various components of the TH synthesis pathway in the thyroid, ultimately leading to decreased secretion of $\mathrm{T}_{4}$ and $\mathrm{T}_{3}$ (Fig. 1).

\section{Illness induced alteration in TH transport}

Cellular entry of $\mathrm{TH}$ is necessary before intracellular conversion of TH by deiodinating enzymes and binding to the nuclear TR can take place. Two categories of TH transporters have been described i.e. the organic anion transporters and the amino acid transporters. The organic anion transporting polypeptide family consists of a variety of homologous proteins of which OATP1C1 is expressed in brain capillaries and in astrocytes where it is involved in the uptake of $\mathrm{T}_{4}$ across the blood-brain barrier (Sugiyama et al. 2003). Well-known amino acid transporters of solute carrier (SLC) group are MCT8 and MCT10. MCT8 transports both $\mathrm{T}_{4}$ and $\mathrm{T}_{3}$ and is expressed in many tissues including liver, kidney and in various brain areas including cortical regions, striatum, cerebellum and hypothalamus (Alkemade et al. 2005, Heuer et al. 2005, Visser et al. 2011). MCT10 preferentially transports $T_{3}$ instead of $\mathrm{T}_{4}$ and is expressed in kidney, liver and muscle (Visser et al. 2011). Once transported into the cell, THs can be metabolized by outer or inner ring deiodination through the iodothyronine deiodinases.

In a rabbit model for prolonged critical illness, hypothalamic Oatp1c1 and Mct10 expression was upregulated, while Mct8 expression was unaltered (Mebis et al. 2009). The functional consequences of these changes were unclear. In mice that received a turpentine injection in the hindlimb, leading to the formation of a sterile abscess, Mct8 as well as D3 (discussed in the following section) was found to be expressed in infiltrating neutrophils (Boelen et al. 2005). The rabbit and mouse studies show that MCT8 does respond to a variety of illnesses, but more extensive studies, including functional studies, will be needed to address this topic in more detail.

\section{TH production and degradation by deiodinases}

THs can be produced and degraded by iodothyronine deiodinating enzymes, so-called deiodinases. These enzymes belong to a selenocysteine containing enzyme family and comprise three types: D1, D2 and D3 (Kohrle 2000). D1 and D2 are $T_{3}$ producing enzymes while D3 inactivates $T_{4}$ and $T_{3}$. The expression and activity levels of all three deiodinases are affected during illness. The basic expression levels of the different deiodinases differ; some organs express predominantly D2 and D3 while other organs showed a limited expression of D2 or D3 but do express D1. The combination of the deiodinases expressed in a cell together or in the same tissue determine the availability of $\mathrm{T}_{3}$ and thereby cellular and tissue function.

\section{Type 1 deiodinase}

The role of D1 in the pathogenesis of NTIS has been extensively studied as D1 is thought to be involved in the production of serum $\mathrm{T}_{3}$ (decreased during illness) via outer ring deiodination and in the clearance of $\mathrm{rT}_{3}\left(\mathrm{rT}_{3}\right.$ concentrations are increased during illness in humans) via inner ring deiodination. D1 is localized in the plasma membrane, and expressed in liver, kidney, thyroid and pituitary. It is positively regulated by $\mathrm{T}_{3}$ (Toyoda et al. 1995, Jakobs et al. 1997). Illness induces a marked decrease in liver D1 mRNA expression and activity in critically ill patients (Peeters et al. 2003, 2005) and in a variety of NTIS animal models (Boelen et al. 1995, 2004a, 2005, 2008, Debaveye et al. 2005).

Published by Bioscientifica Ltd. 


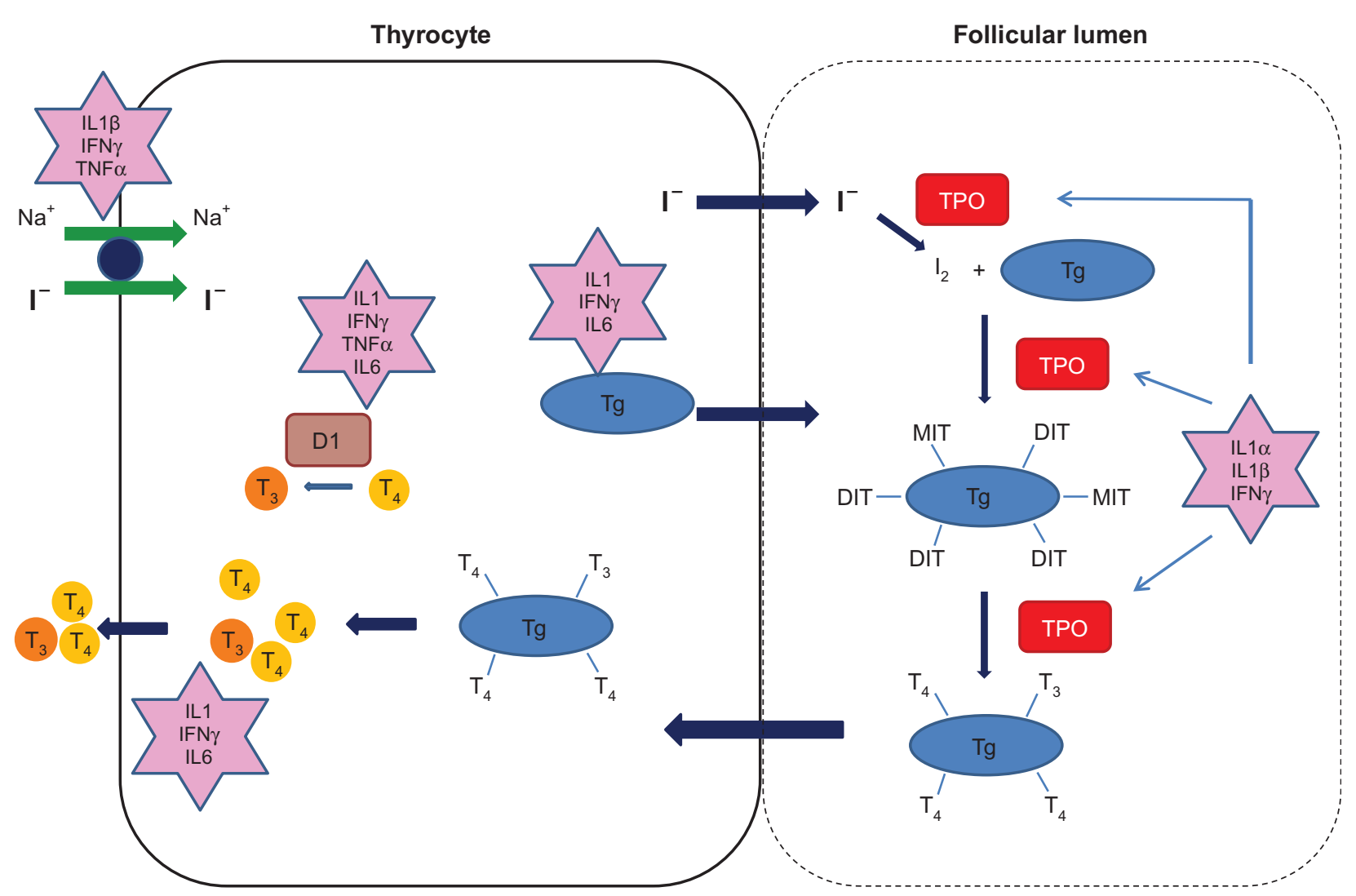

Figure 1

Cytokines have direct inhibitory effects on components of the thyroid hormone synthesis pathway in the thyrocyte. Cytokines diminish the uptake of iodide by the natrium/iodide symporter (NIS). Thyroglobulin (Tg) is synthesized within the follicular cells and is transported into the follicular lumen. The transcription of $\mathrm{Tg}$ is inhibited by cytokines. In the lumen, thyroid peroxidase (TPO) is a key enzyme in the formation of TH. It oxidizes $\mathrm{I}^{-}$to $\mathrm{I}_{2}$ and subsequently organifies the $\mathrm{I}_{2}$ by linking it to the tyrosin residues on the Tg protein forming mono-iodotyrosine (MIT) and di-iodotyrosine (DIT). TPO subsequently combines MIT and DIT to form triiodothyronine $\left(T_{3}\right)$ or two DIT residues to form thyroxine $\left(T_{4}\right)$. TPO expression and function is inhibited by cytokines. After endocytosis into the follicular cell, $\mathrm{Tg}$ is broken down thereby releasing $\mathrm{T}_{4}$ and $\mathrm{T}_{3}$. Additional $T_{3}$ is formed by deiodination of $T_{4}$ by type 1 deiodinase (D1) which is also inhibited by cytokines.
The Dio1 gene is activated via a TR/RXR heterodimer which indicates that decreased Dio1 expression may result from reduced $\mathrm{TR}$ or/and reduced RXR expression. $\mathrm{T}_{3}$ positively regulates the expression of Dio1 via TR $\beta$ mediated binding to TH responsive elements in the Dio1 promoter and functional $\operatorname{TR} \beta$ signaling is therefore essential for basal expression of Dio1 (Amma et al. 2001). Liver TR $\beta$ expression is downregulated during acute inflammation in mice (Beigneux et al. 2003, Boelen et al. $2004 a$ ). In vitro studies suggest a major role for cytokines, as IL1 $\beta$ decreases TR $\beta$ mRNA expression in a human hepatoma cell line (HepG2; Kwakkel et al. 2006). Furthermore, TNF $\alpha$, IL1 and IL6 decrease the binding capacity of $\mathrm{T}_{3}$ to the TR (Jakobs et al. 1997). An important intracellular signalling pathway for cytokines is the nuclear factorkappa B (NF-кB) pathway. Nagaya et al. (2000) show that
TNF $\alpha$ impairs the $\mathrm{T}_{3}$ dependent induction of Dio1 expression in HEPG 2 cells via interference of NF- $\kappa \mathrm{B}$ with TR function. There is, however, no evidence for a direct interaction between the TR and NF- $\kappa \mathrm{B}$ which suggests a common cofactor by NF- $\mathrm{B}$ and the TR to play a role (Nagaya et al. 2000).

Although it was assumed that mainly the TR $\beta$ was involved in the illness induced D1 repression in the liver, studies in $\mathrm{TR} \beta^{\mathrm{O} / 0}$ and $\mathrm{TR} \alpha^{0 / 0}$ mice show that while the LPS induced D1 decrease is still present in the $\operatorname{TR} \beta^{0 / 0}$ mice, this response is attenuated in the $\mathrm{TR} \alpha^{0 / 0}$ mice (Kwakkel et al. $2008,2010)$. In addition, the IL1 $\beta$ induced decrease in TR $\beta$ mRNA expression in HepG2 cells is solely dependent on NF- $\kappa \mathrm{B}$ signaling, while the decreases in Dio1 and $\mathrm{TR} \alpha$ are dependent on both NF- $\kappa \mathrm{B}$ and activator protein-1 (AP-1) signaling (Kwakkel et al. 2006, 2007). This suggests that

Published by Bioscientifica Ltd 
diminished expression of the TR $\beta$ by itself is not the only factor in the illness induced liver Dio1 decrease.

An very elegant alternative mechanism for TR $\beta$ mediated repression of liver D1 during acute inflammation has been proposed by $\mathrm{Yu}$ et al., who showed both in vivo and in vitro that adding exogenous co-activator steroid receptor co-activator-1 (SRC-1) attenuates the illness induced liver D1 decrease (Yu \& Koenig 2000, 2006). These studies indicate that competition for limiting amounts of SRC-1, which is a shared coactivator for TR and inflammatory signaling pathways, is one of the mechanisms involved in the illness induced D1 decrease. Indeed, restoration of liver Dio1 expression by exogenous SRC-1 prevents the fall in serum TH levels after LPS (Yu \& Koenig 2000, 2006).

After LPS administration, hepatic RXR $\alpha$ protein rapidly migrates to the cytoplasma where it can be degraded. This process is mediated by the inflammatory pathway JNK (Beigneux et al. 2000). However, the IL1 $\beta$ induced decrease of liver Dio1 mRNA is not prevented by inhibition of JNK alone (Kwakkel et al. 2006), which makes it unlikely that RXR is solely responsible for the illness induced decrease in liver Dio1.

An additional possibility is that decreased amounts of a specific co-factor glutathione (GSH), required for D1 catalytic activity (Goswami \& Rosenberg 1987) may play a role in the illness induced decrease of liver D1 activity. D1 activity in intact liver cells can be suppressed by IL6 and the addition of $\mathrm{N}$-acetyl-cysteine, an antioxidant that restores intracellular GSH levels, prevents the IL6-induced suppression of D1 (Wajner et al. 2011, Fig. 2).

Although these studies provide mechanisms behind the illness induced D1 decrease in the liver, the importance of this decrease for the development of NTIS is questioned by studies in D1/D2 knock out mice, showing similar responses to LPS administration with regard to changes in serum $\mathrm{T}_{4}$ and $\mathrm{T}_{3}$ compared to WT littermates (St Germain et al. 2009). Although it is unknown at present whether a lack of D1 affects the illness induced liver $\mathrm{T}_{3}$ concentrations, it has been shown in critically ill rabbits that the suppression of liver D1 activity was correlated with decreased hepatic $\mathrm{T}_{3}$ concentrations (Debaveye et al. 2008).

\section{Type 2 deiodinase}

D2 is localized in the endoplasmic reticulum and deiodinates $\mathrm{T}_{4}$ into the biologically active $\mathrm{T}_{3}$. D2 is the main enzyme involved in the production of tissue $T_{3}$ and is therefore heavily involved in local TH metabolism.
D2 is negatively regulated by $\mathrm{TH}$, both pre- and posttranscriptionally, as $T_{3}$ down regulates Dio2 mRNA expression (Burmeister et al. 1997), while $\mathrm{T}_{4}$ as well as $\mathrm{rT}_{3}$ (both substrates for $\mathrm{D} 2$ ) affect $\mathrm{D} 2$ activity via increasing D2 ubiquitination and subsequent proteasomal degradation (Sagar et al. 2007).

Many studies have focused on the role of D2 in the central part of HPT axis as the setpoint of the central HPT axis that is altered during illness. The unresponsiveness of the HPT axis to low serum TH levels has been suggested to be mediated by increased production of $\mathrm{T}_{3}$ via elevated $\mathrm{D} 2$ activity in tanycytes (Fekete et al. 2004) as mice lacking the TR $\beta$ do not show an illness induced hypothalamic Trh decrease (Boelen et al. 2009a). In addition, global D2 knock out mice do not show a suppression of Trh upon LPS stimulation (Freitas et al. 2010).

The inflammation induced D2 upregulation in the hypothalamus was found to be independent of the fall in serum $\mathrm{TH}$ concentrations, in contrast to D2 expression in other brain areas like the cortex and in the pituitary (Fekete et al. 2005). A role for inflammatory cytokines was suggested as LPS administration results in a rapid increase of pro-inflammatory cytokines including TNF $\alpha$, IL1 and IL6. The Dio2 promoter contains NF-кB responsive elements and is thus sensitive to inflammatory signal transduction pathways (Fekete et al. 2004, Zeold et al. 2006). NF- $\mathrm{B}$ B is therefore highlighted as a possible mediator of the inflammation induced increase in Dio2 expression in the hypothalamus.

In vitro, NF- $\mathrm{KB}$ is able to induce Dio2 expression in mesothelioma cells endogenously expressing D2 (Zeold et al. 2006). In a primary culture of rat astrocytes and human glioma cells, LPS induces Dio2 mRNA expression via the NF- $\mathrm{KB}$ and MAPK pathways (Lamirand et al. 2011). However, the significance of these findings with regard to NTIS are debatable, since the changes in Dio2 expression occur relatively late in astrocytes compared to tanycytes. Stimulation of primary tanycytes with LPS also results in an increase of Dio2 expression. This effect can be completely blocked when the transcriptional activity of the NF-кB pathway is inhibited (de Vries et al. 2014a) indicating an important role for NF-кB in the relevant cell type. These results will have to be replicated in vivo, since a study by Sanchez et al. (2010) showed that Iк-B $\alpha$, a marker for NF- $\kappa \mathrm{B}$ activation, is expressed secondary to the rise in Dio2 in tanycytes after LPS administration in rats.

During fasting, a rise in D2 activity in the hypothalamus is also observed, however the magnitude of this response is marginal compared to the increase in D2 activity during inflammation. Furthermore, the

Published by Bioscientifica Ltd 


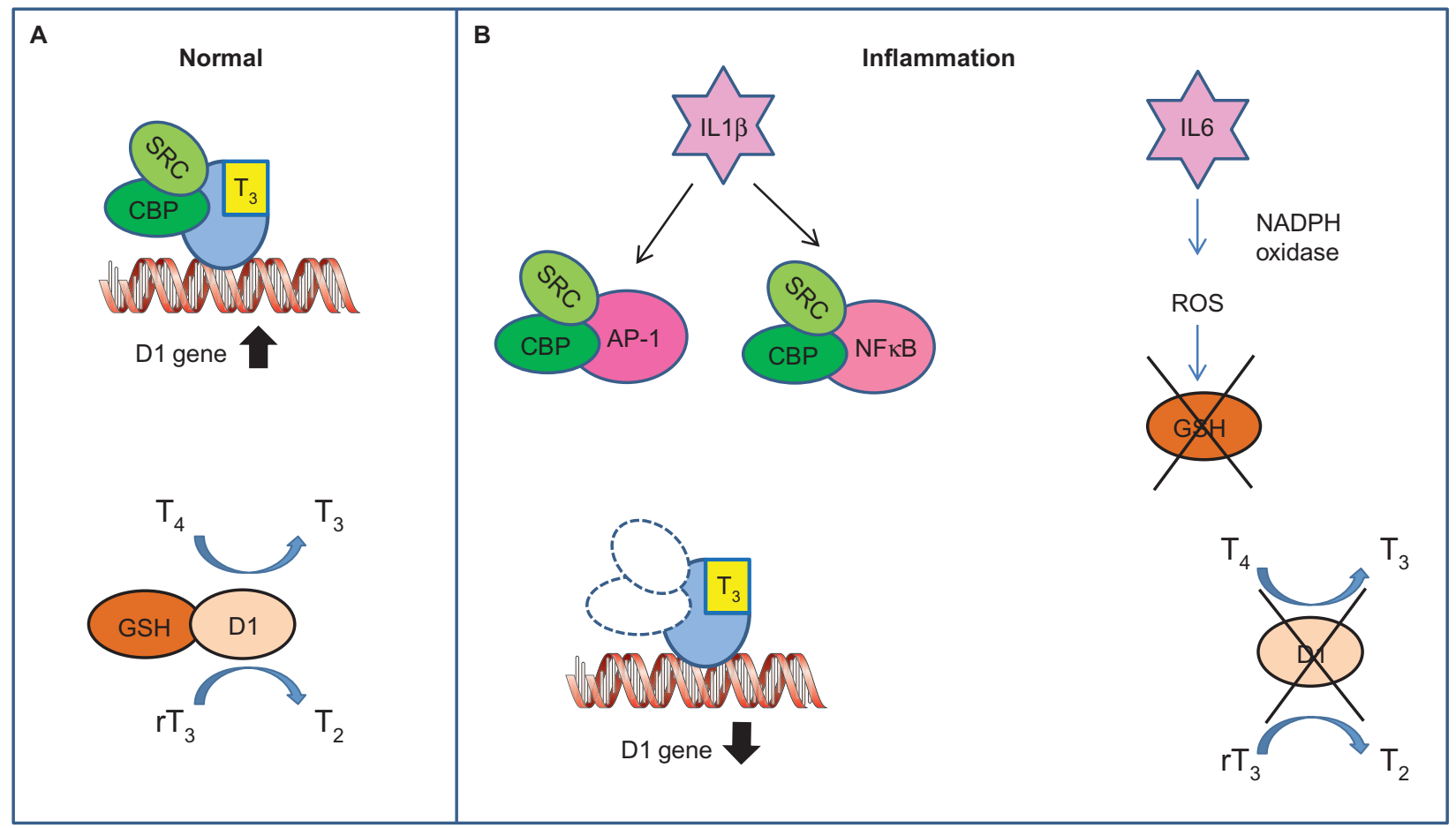

Figure 2

Schematic representation of the mechanisms involved in the inflammationinduced inhibition of type 1 deiodinase (D1) expression and activity. (A) Under physiological conditions, thyroid hormone receptor (TR) mediated gene transcription needs the presence of co-factors such as steroid receptor co-activator (SRC). D1 is dependent on cofactors such as glutathione (GSH).

mechanisms behind the fasting induced increase in D2 are different and dependent on leptin, corticosterone and changes in neuropeptide expression (Diano et al. 1998).

D2 is expressed in skeletal muscle (Bianco \& Kim 2006) and is thought to be involved in the peripheral production of $\mathrm{T}_{3}$ under basal circumstances (Maia et al. 2005). Dio2 expression in skeletal muscle increases in intensive-care unit patients (Mebis et al. 2007), in several NTIS animal models of acute (Kwakkel et al. 2008) and chronic inflammation (Kwakkel et al. 2009), while in septic patients and mice muscle Dio2 expression decreases (Rodriguez-Perez et al. 2008, Kwakkel et al. 2009). The increased Dio2 expression during chronic inflammation is likely due to enhanced CREB signalling (Kwakkel et al. 2009), while the decrease during sepsis might be mediated by decreased food intake since $62 \mathrm{~h}$ of fasting decreased muscle Dio2 expression in healthy volunteers (Heemstra et al. 2009) (see Fig. 3).

Like inflammation, hypothyroidism increases D2 activity in the hindlimb muscle of mice (Marsili et al. 2010). The increased production of $T_{3}$ in muscle by $D 2$ plays an important role during myogenesis, muscle
(B) During inflammation, competition for co-factors by cytokine induced pathways such as activator protein-1 (AP-1) and/or nuclear factor-kappa B (NF-KB) leads to less TR mediated transcription of the Dio1 gene. Cytokines are also able to produce reactive oxygen species via the NADPH oxidase pathway which depletes the available GSH thereby diminishing D1 activity.

regeneration and differentiation, and is mediated via the forkhead box O3 (FoxO3) pathway (Dentice et al. 2010, Marsili et al. 2011). Fox transcription factors are a class of transcription factors that bind to forkhead regulatory elements in the DNA and regulate a variety of cell functions (Accili \& Arden 2004). Whether the FoxO3 pathway also plays a role in the inflammation induced $\mathrm{D} 2$ increase remains questionable at this stage.

D2 is also expressed in the lung, although the significance in the healthy adult lung is unknown (Escobar-Morreale et al. 1997, Ohba et al. 2001). During LPS induced lung injury (caused by intranasal LPS administration) and ventilator-induced lung injury (VILI) in mice, the expression of $\mathrm{D} 2$ in the lung is increased ( $\mathrm{Ma}$ et al. 2011). In addition, D2 protein expression is increased in human microvascular endothelial cells that are subjected to cyclic stretch (Ma et al. 2011). The increase in D2 expression and the subsequent rise in local $\mathrm{T}_{3}$ concentrations might be an adaptive and protective mechanisms of the lung to prevent lung damage during inflammation, since knocking down D2 in vivo aggravates lung injury after VILI

Published by Bioscientifica Ltd. 


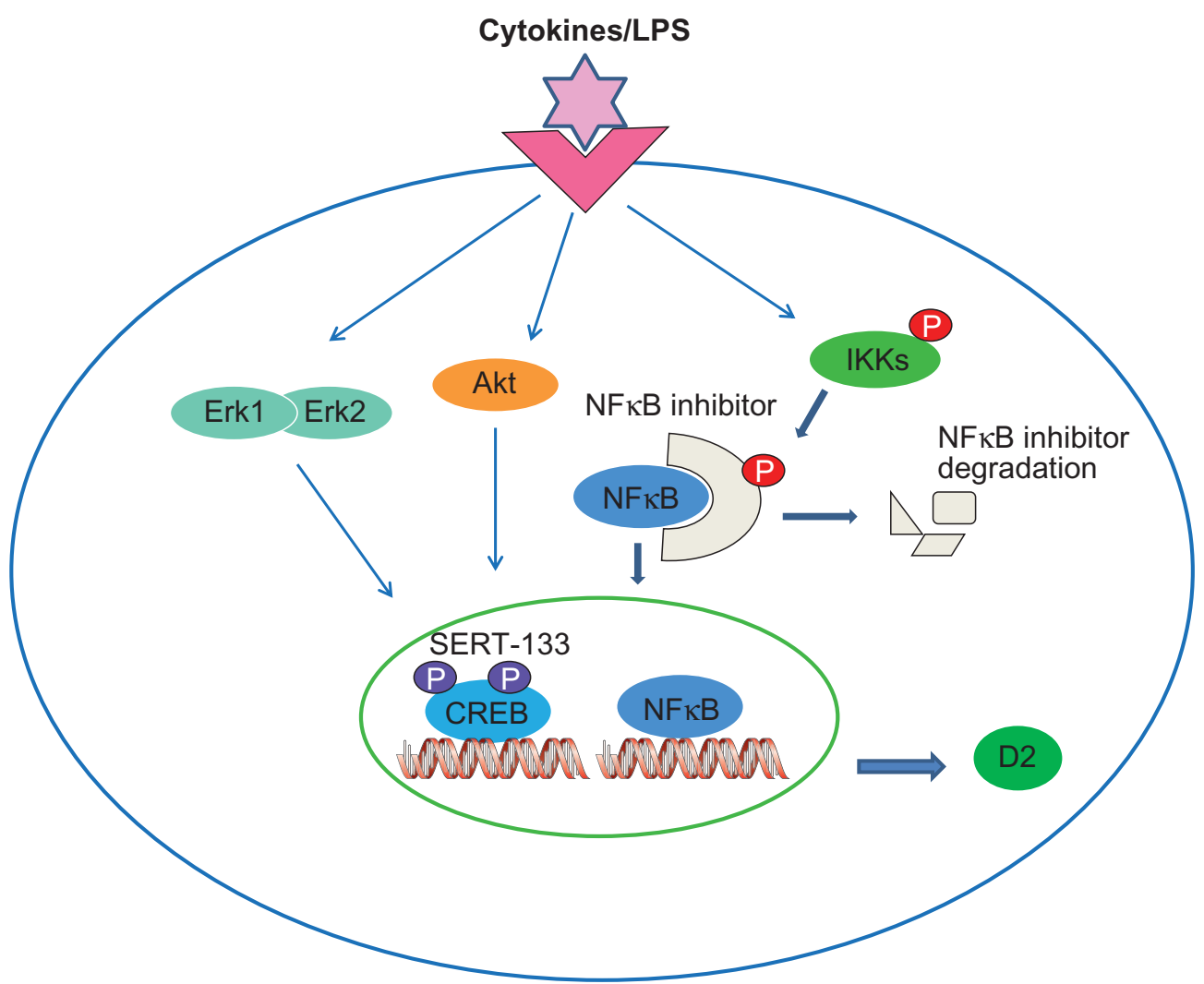

Figure 3

Schematic overview of the activation of type 2 deiodinase (Dio2) gene transcription by cytokines. Cytokines or LPS bind to their respective receptors. This leads to activation of IkB kinase (IKK), a kinase that phosphorylates the NF- $\kappa B$ inhibitor IkB. This is followed by degradation of

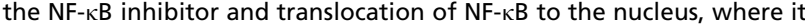

(Barca-Mayo et al. 2011, Ma et al. 2011). VILI leads to local increases of TNF $\alpha$, IL6 and IL1 $\beta$, again suggesting the involvement of cytokines in the upregulation of Dio2 (Barca-Mayo et al. 2011) via NF- $\kappa \mathrm{B}$ activation (Lentsch et al. 1998, Leeper-Woodford \& Detmer 1999). Indeed, inhibiting $\mathrm{NF}-\kappa \mathrm{B}$ activation protects mice from LPS induced acute lung injury (Wang et al. 2013).

Interestingly, $\mathrm{TH}$ metabolism is also tightly linked with the innate immune system. Increased expression of Dio2 is found in resident macrophages in the liver upon chronic and acute inflammation. However, this is not mediated by NF- $\kappa \mathrm{B}$ and the mechanisms involved are unknown to date (Kwakkel et al. 2014).

D2 is homeostatically regulated by a post transcriptional mechanism involving ubiquitination mediated conformational changes and subsequent proteosomal degradation, explaining its short half-life compared to the other deiodinases. This mechanism was first described activates Dio2 gene transcription. Cytokines also activate protein kinase B (Akt) and Erk signaling pathways via binding to cytokine receptors which subsequently results in phosphorylation of CAMP responsive element binding protein (CREB), thereby activating Dio2 transcription.

by Gereben et al. (2000) and was shown to be induced by the major substrate of $\mathrm{D} 2, \mathrm{~T}_{4}$. Ubiquitination of $\mathrm{D} 2$ by the ubiquitin conjugating enzymes UBC6 and UBC7 is mediated via WSB-1 (a D2 specific E3 ubiguitin ligase adaptor subunit) which changes the conformation of the D2 dimer and thus its catalytic activity (Sagar et al. 2007). D2 can be reactivated by de-ubiquitination by the deubiquitinating enzyme USP-33 (Curcio-Morelli et al. 2003). In tanycytes, both WSB-1 and USP-33 are coexpressed with D2 (Fekete et al. 2007). Recent studies, however, show that $\mathrm{T}_{4}$ induced ubiquitination in tanycytes is minimal, probably to ensure the sensitivity of the TRH producing neurons in the PVN to fluctuations in serum TH concentrations (Werneck de Castro et al. 2015). In line with these findings, there is no evidence that ubiquitination is involved in the regulation of D2 during inflammation. Also in muscle, where D2 expression and activity is increased upon inflammation, WSB-1 and

Published by Bioscientifica Ltd 
USP-33 expression is not correlated with the increased D2 activity during chronic inflammation and sepsis (Kwakkel et al. 2009).

\section{Type 3 deiodinase}

D3 is localized in the plasma membrane and can be viewed as the major $\mathrm{TH}$ inactivating enzyme, as it catalyzes inner-ring deiodination of both $\mathrm{T}_{4}$ and $\mathrm{T}_{3}$, exclusively resulting in the production of biologically inactive $\mathrm{rT}_{3}$ and $\mathrm{rT}_{2}$ (Kohrle 2000). D3 is highly expressed in the placenta during fetal development, thereby protecting the fetus from an overexposure of $\mathrm{T}_{3}$ (Darras et al. 1999). In the adult organism, D3 is expressed in neurons in the brain, the liver and in parts of the innate immune system, although physiological levels are very low (Gereben et al. 2008).

Illness influences D3 expression and activity in the liver, but the results from animal studies vary. While during acute and chronic inflammation and during sepsis liver Dio3 mRNA expression and activity levels are decreased (Boelen et al. 2005, 2008), hepatic D3 expression and activity are increased in rabbits with prolonged critical illness (Debaveye et al. 2005). Slightly increased D3 activity is also observed in the livers of severely ill patients (Peeters et al. 2003).

During prolonged critical illness, decreased food intake might be an important factor in regulating liver deiodinases. Fasting for $36 \mathrm{~h}$ or a $50 \%$ reduction in food intake for 3 weeks results in pronounced increase of D3 expression and activity in the liver (de Vries et al. 2014b). As prolonged illness is associated with persistently diminished food intake, the differences in D3 activity between the several illness models might be explained by the dominant role of reduced food intake. One of the hormones sensitive to food intake is leptin. Acute and chronic inflammation increase serum leptin via IL1 $\beta$ (Faggioni et al. 1998) while prolonged critical illness decrease serum leptin levels. The drop in leptin is known to be important for the increase in D3 activity during fasting in mice (Boelen et al. 2012) and might thus also be important for the regulation of D3 during illness.

Illness induces changes in muscle D3 expression that depend on the type and timing of the illness. While acute inflammation decreases muscle D3 (Kwakkel et al. 2010), bacterial sepsis does not affect D3 and chronic inflammation even increases D3 expression (Kwakkel et al. 2009). In critically ill patients, muscle D3 is also increased (Peeters et al. 2003). These changes seem to be independent on inflammatory pathways since neither sepsis nor chronic inflammation induces phosphorylation of the NF- $\mathrm{B}$ and ERK pathways (Kwakkel et al. 2009). In proliferating myoblasts, D3 functions as a survival factor by decreasing $\mathrm{TH}$ concentrations and suppressing $\mathrm{TH}$ induced FoxO3 mediated gene expression (Dentice et al. 2014). In contrast, during muscle cell differentiation, inhibition of D3 gene expression is mediated by histone H3 demethylating enzyme (LSD-1) that relieved activation marks on the D3 promoter and at the same time activates D2 expression by removing the repressive marks on the D2 promoter in a reciprocal fashion (Ambrosio et al. 2013). Whether these epigenetic modifications of deiodinase gene expression are also important during inflammation remains to be investigated.

In cardiomyocytes, D3 expression is low under physiological conditions. Myocardial infarction and pressure induce hypertrophy in rats lead to an upregulation of D3 activity (Wassen et al. 2002, Olivares et al. 2007). It was postulated that the increase in D3 in peripheral organs might be regulated by hypoxia due to decreased tissue perfusion during illness (Peeters et al. 2003), and this assumption is supported by the observation that both D3 and hypoxia-inducible factor 1 alpha (HIF1 $\alpha$ ) are upregulated in the hypertrophic heart. Furthermore, HIF1 $\alpha$ appeared to regulate D3 expression in a variety of cell lines under hypoxic conditions (Simonides et al. 2008). HIF1 $\alpha$ activity is regulated by prolyl hydroxylases (PHD's) that prime HIF1 $\alpha$ for degradation (Aragones et al. 2009). Both oxygen and 2-oxoglutarate (2-OG) are necessary cofactors for PHD's and therefore involved in HIF1 $\alpha$ regulation. Under hypoxic conditions, HIF1 $\alpha$ stabilizes and translocates to the nucleus, dimerizes with HIF $1 \beta$ and activates Dio3 gene transcription (Simonides et al. 2008). However, decreased concentrations of 2-OG might also play a role in the stabilization of HIF $1 \alpha$ as diminished food intake, frequently observed during illness, could result in decreased concentrations of 2-OG due to glucagon and increased gluconeogenic flux (Ochs 1984). In addition, during inflammation NF- $\kappa$ B also directly enhances HIF1 $\alpha$ gene transcription, thereby increasing total HIF1 $\alpha$ availability (Oliver et al. 2009, Fig. 4).

It was recently shown that the upregulation of D3 during myocardial infarction is also associated with increased expression of a specific set of microRNA's that might enhance the proliferative capacity of the cardiomyocytes (Janssen et al. 2013).

In addition to the organs and tissues mentioned, D3 is also expressed by infiltrating polymorphonuclear leukocytes upon the induction of a sterile abscess by turpentine injection in the hindlimb (Boelen et al. 2005). In addition,

Published by Bioscientifica Ltd. 


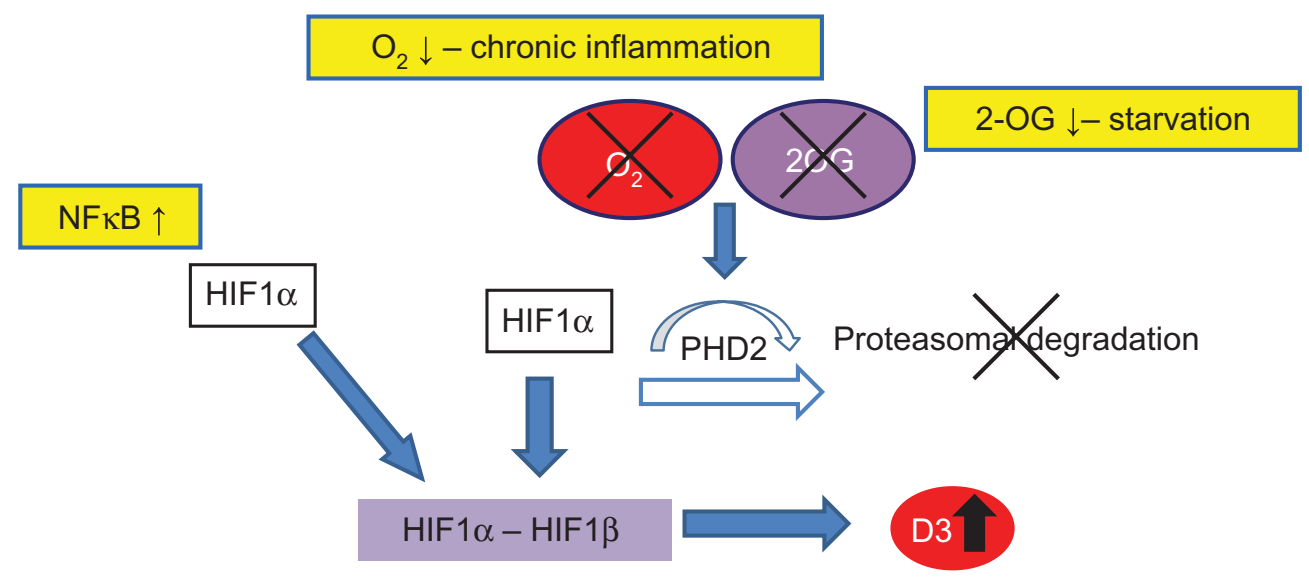

\section{Figure 4}

Schematic representation of mechanisms supposed to be involved in D3 regulation during illness. HIF $1 \alpha$ is a protein that is regulated posttranscriptionally by proteasomal degradation. When oxygen and 2-oxoglutarate (2-OG) are present, HIF1 $\alpha$ is hydroxylated by a class of enzymes called prolyl hydroxylases (PHD's) which makes HIF1 $\alpha$ prone to degradation. When oxygen or 2-OG are low during Illness (due to

peritonitis induced by $E$. coli and pneumonia induced by $S$. pneumoniae stimulates D3 expression in infiltrating granulocytes in the liver and lungs respectively (Boelen et al. 2008). Granulocytes are part of the innate immune system and have intracellular bacterial killing mechanisms such as the myeloperoxidase (MPO) system (Klebanoff 2005). It is hypothesized that following bacterial infection, the increased activity of D3 provides the MPO system with $\mathrm{I}^{-}$that is released when the deiodination of $\mathrm{T}_{3}$ and $\mathrm{T}_{4}$ takes place to ensure an effective microbial killing machinery (Boelen et al. 2008). However, the mechanisms involved in the increase in D3 activity in activated neutrophils are currently unknown.

Although previously assumed otherwise, increased tissue D3 activity is not involved in the illness induced alterations in serum TH concentrations, since D3 knock out and WT mice showed similarly decreased serum TH concentrations during inflammation (Boelen et al. 2009b).

\section{TH production and degradation by alternative pathways}

$\mathrm{TH}$ are also metabolized in peripheral tissues via alternative pathways. Many of these processes take place in the liver. $\mathrm{T}_{3}$ and $\mathrm{T}_{4}$ can be conjungated to a sulphate group at the phenolic hydroxyl group, producing sulphated $\mathrm{T}_{3}$ $\left(\mathrm{T}_{3} \mathrm{~S}\right)$ and sulphated $\mathrm{T}_{4}\left(\mathrm{~T}_{4} \mathrm{~S}\right) . \mathrm{T}_{3} \mathrm{~S}$ has no affinity for the TR, while sulfated $\mathrm{TH}$ is prone to degradation by D1 (Mol \& Visser 1985, Visser et al. 1998). Sulfation is mediated by decreased tissue perfusion or reduced food intake respectively), PHD's do not hydroxylate HIF1 $\alpha$, resulting in its stabilization and translocation to the nucleus where it dimerizes with constitutively expressed HIF1 $\beta$ and activates gene transcription. Upon inflammation, NF- $\mathrm{KB}$ is also able to induce HIF1 $\alpha$ transcription which could contribute to D3 regulation.

sulfotransferases (Sults), a family of enzymes that sulfate both endogenous and exogenous substances, and is also dependent of the availability of specific cofactors (3'-phosphoadenosine-5'-phosphosulfate) and the availability of inorganic sulfate (Kaptein et al. 1997). Not much is known about the activity of Sults during illness. In serum of patients who died in the ICU, the $T_{4} S$ concentrations are significantly elevated, but this is due to a decrease in clearance by D1 and not to increased Sult activity (Peeters et al. 2005). Furthermore, changes in sulfate availability during illness and diminished food intake could also play a role. In addition to sulfation, $\mathrm{TH}$ can be glucuronidated by UDP-glucuronosyltransferases (UGTs; Taurog et al. 1952). $\mathrm{T}_{4}$, and to a lesser extent $\mathrm{T}_{3}$, are substrates of a variety of UGT iso-enzymes. Glucuronidation facilitates the excretion of $\mathrm{TH}$ via the bile and feces (Tukey \& Strassburg 2001). No alterations have been described in glucuronidation during critical illness per se, but methodological issues include increased glucuronidation due to the administration of drugs (Visser 1994) which will further decrease $\mathrm{T}_{4}$ concentrations in ill patients.

A way of TH metabolism that is less well studied is ether link cleavage (ECL). This involves the breaking of the ether bridge in between the two tyrosines, yielding diiodotyrosine as a main product. This reaction is catalyzed by peroxidases, such as MPO that is present in leukocytes. In vitro, exposure to zymosan (a compound of yeast that induces phagocytosis) increased breakdown

Published by Bioscientifica Ltd. 
of $\mathrm{T}_{4}$ and $\mathrm{T}_{3}$ by ECL in leukocytes (Burger et al. 1983), indicating that this mechanism, besides deiodination, might be important for the bacterial killing machinery in the leukocyte. The role of ECL in TH metabolism under physiological conditions is thought to be limited, since only $5 \%$ of total body clearance of TH is mediated via ELC (Faber et al. 1989). However, it has been suggested that the serum concentration of DIT, a product of ELC, increase after surgery and during sepsis (Gramm et al. 1989, Meinhold et al. 1991), indicating that in specific pathophysiological conditions, ECL might attribute to $\mathrm{TH}$ clearance.

\section{Concluding remarks}

Several mechanisms are known to be involved in the illness induced alterations in the HPT axis and TH target tissues:

i) The illness induced suppression of TRH in the PVN is hypothesized to be mediated by increased $T_{3}$ production via increased D2 expression in tanycytes. Studies using specific inhibitors reported a causal role for NF- $\mathrm{KB}$ in the upregulation of D2. However, no conclusive data is available whether the induction of D2 observed in illness results in increased local $T_{3}$ concentrations.

ii) Whether the decreased thyroidal secretion during illness is due to central suppression of the HPT axis or to a direct inhibitory effect of cytokines on the thyroid gland is still unclear. In vitro studies showed that a variety of pro-inflammatory cytokines are able to inhibit crucial steps involved in TH production, from iodide uptake to $\mathrm{TH}$ secretion.

iii) The D1 decrease in liver during illness is likely due to suppressed TR signalling, possibly mediated by NF- $\mathrm{KB}, \mathrm{AP}-1$ and competition for common cofactors. Whether the suppression of liver D1 is causal for the illness induced decrease in serum $\mathrm{T}_{3}$ is uncertain.

iv) Changes in D2 and D3 are observed in muscle, innate immune cells, adipose tissue and lung (D2) during illness. Inflammatory pathways might play a role, although NF- $\kappa \mathrm{B}$ is not involved in the D2 increase in muscle and macrophages. Activation of the CREB pathway may be involved in the regulation of D2 in muscle.

More studies will be necessary to further define the underlying mechanisms and more importantly, to investigate the functional consequences of the changes in $\mathrm{TH}$ metabolism for cellular function. Ultimately, thorough knowledge of the pathogenesis and role of NTIS in critical illness may help to improve clinical outcome through targeted interventions in $\mathrm{TH}$ metabolism.

\section{Declaration of interest}

The authors declare that there is no conflict of interest that could be perceived as prejudicing the impartiality of this review.

\section{Funding}

This review did not receive any specific grant from any funding agency in the public, commercial or not-for-profit sector.

\section{References}

Accili D \& Arden KC 2004 FoxOs at the crossroads of cellular metabolism, differentiation, and transformation. Cell 117 421-426. (doi:10.1016/ S0092-8674(04)00452-0)

Ajjan RA, Watson PF, Findlay C, Metcalfe RA, Crisp M, Ludgate M \& Weetman AP 1998 The sodium iodide symporter gene and its regulation by cytokines found in autoimmunity. Journal of Endocrinology 158 351-358. (doi:10.1677/joe.0.1580351)

Alkemade A, Friesema EC, Unmehopa UA, Fabriek BO, Kuiper GG, Leonard JL, Wiersinga WM, Swaab DF, Visser TJ \& Fliers E 2005 Neuroanatomical pathways for thyroid hormone feedback in the human hypothalamus. Journal of Clinical Endocrinology and Metabolism 90 4322-4334. (doi:10.1210/jc.2004-2567)

Alkemade A, Friesema EC, Kuiper GG, Wiersinga WM, Swaab DF, Visser TJ \& Fliers E 2006 Novel neuroanatomical pathways for thyroid hormone action in the human anterior pituitary. European Journal of Endocrinology 154 491-500. (doi:10.1530/eje.1.02111)

Ambrosio R, Damiano V, Sibilio A, De Stefano MA, Avvedimento VE, Salvatore D \& Dentice M 2013 Epigenetic control of type 2 and 3 deiodinases in myogenesis: role of lysine-specific demethylase enzyme and FoxO3. Nucleic Acids Research 41 3551-3562. (doi:10.1093/nar/ gkt065)

Amma LL, Campos-Barros A, Wang Z, Vennstrom B \& Forrest D 2001 Distinct tissue-specific roles for thyroid hormone receptors $\beta$ and $\alpha 1$ in regulation of type 1 deiodinase expression. Molecular Endocrinology 15 467-475. (doi:10.1210/mend.15.3.0605)

Aragones J, Fraisl P, Baes M \& Carmeliet P 2009 Oxygen sensors at the crossroad of metabolism. Cell Metabolism 9 11-22. (doi:10.1016/j.cmet. 2008.10.001)

Asakawa H, Miyagawa J, Kobayashi T, Hanafusa T, Kuwajima M \& Matsuzawa Y 1996 Effects of interleukin-1 $\beta$ on scanning electron microscopic appearance and thyroid peroxidase content of human thyrocytes in monolayer culture. Immunopharmacology 34 131-137. (doi:10.1016/0162-3109(96)00126-9)

Ashizawa K, Yamashita S, Nagayama Y, Kimura H, Hirayu H, Izumi M \& Nagataki S 1989 Interferon- $\gamma$ inhibits thyrotropin-induced thyroidal peroxidase gene expression in cultured human thyrocytes. Journal of Clinical Endocrinology and Metabolism 69 475-477. (doi:10.1210/jcem69-2-475)

Barca-Mayo O, Liao XH, DiCosmo C, Dumitrescu A, Moreno-Vinasco L, Wade MS, Sammani S, Mirzapoiazova T, Garcia JG, Refetoff S et al. 2011 Role of type 2 deiodinase in response to acute lung injury (ALI) in mice. PNAS 108 E1321-E1329. (doi:10.1073/pnas.1109926108)

Bartalena L, Bogazzi F, Brogioni S, Grasso L \& Martino E 1998 Role of cytokines in the pathogenesis of the euthyroid sick syndrome. European Journal of Endocrinology 138 603-614. (doi:10.1530/eje.0.1380603)
(C) 2015 Society for Endocrinology Printed in Great Britain 
Beigneux AP, Moser AH, Shigenaga JK, Grunfeld C \& Feingold KR 2000 The acute phase response is associated with retinoid $\mathrm{X}$ receptor repression in rodent liver. Journal of Biological Chemistry 275 16390-16399. (doi:10.1074/jbc.M000953200)

Beigneux AP, Moser AH, Shigenaga JK, Grunfeld C \& Feingold KR 2003 Sick euthyroid syndrome is associated with decreased TR expression and DNA binding in mouse liver. American Journal of Physiology. Endocrinology and Metabolism 284 E228-E236. (doi:10.1152/ajpendo. 00155.2002)

Bianco AC \& Kim BW 2006 Deiodinases: implications of the local control of thyroid hormone action. Journal of Clinical Investigation 116 2571-2579. (doi:10.1172/JCI29812)

Boelen A, Platvoet-Ter Schiphorst MC \& Wiersinga WM 1993 Association between serum interleukin- 6 and serum 3,5,3'-triiodothyronine in nonthyroidal illness. Journal of Clinical Endocrinology and Metabolism $7 \mathbf{7}$ 1695-1699. (doi:10.1210/jcem.77.6.8263160)

Boelen A, Platvoet-Ter Schiphorst MC, Bakker O \& Wiersinga WM 1995 The role of cytokines in the lipopolysaccharide-induced sick euthyroid syndrome in mice. Journal of Endocrinology 146 475-483. (doi:10.1677/ joe.0.1460475)

Boelen A, Maas MA, Lowik CW, Platvoet MC \& Wiersinga WM 1996 Induced illness in interleukin-6 (IL-6) knock-out mice: a causal role of IL-6 in the development of the low 3,5,3'-triiodothyronine syndrome. Endocrinology 137 5250-5254. (doi:10.1210/endo.137.12.8940342)

Boelen A, Kwakkel J, Thijssen-Timmer DC, Alkemade A, Fliers E \& Wiersinga WM 2004a Simultaneous changes in central and peripheral components of the hypothalamus-pituitary-thyroid axis in lipopolysaccharide-induced acute illness in mice. Journal of Endocrinology 182 315-323. (doi:10.1677/joe.0.1820315)

Boelen A, Kwakkel J, Platvoet-ter Schiphorst M, Baur A, Kohrle J \& Wiersinga WM 2004b Contribution of interleukin-12 to the pathogenesis of non-thyroidal illness. Hormone and Metabolic Research 36 101-106. (doi:10.1055/s-2004-814219)

Boelen A, Kwakkel J, Platvoet-ter Schiphorst M, Mentrup B, Baur A, Koehrle J \& Wiersinga WM 2004c Interleukin-18, a proinflammatory cytokine, contributes to the pathogenesis of non-thyroidal illness mainly via the central part of the hypothalamus-pituitary-thyroid axis. European Journal of Endocrinology 151 497-502. (doi:10.1530/eje.0.1510497)

Boelen A, Kwakkel J, Alkemade A, Renckens R, Kaptein E, Kuiper G, Wiersinga WM \& Visser TJ 2005 Induction of type 3 deiodinase activity in inflammatory cells of mice with chronic local inflammation. Endocrinology 146 5128-5134. (doi:10.1210/en.2005-0608)

Boelen A, Kwakkel J, Wiersinga WM \& Fliers E 2006 Chronic local inflammation in mice results in decreased TRH and type 3 deiodinase mRNA expression in the hypothalamic paraventricular nucleus independently of diminished food intake. Journal of Endocrinology 191 707-714. (doi:10.1677/joe.1.07056)

Boelen A, Boorsma J, Kwakkel J, Wieland CW, Renckens R, Visser TJ, Fliers E \& Wiersinga WM 2008 Type 3 deiodinase is highly expressed in infiltrating neutrophilic granulocytes in response to acute bacterial infection. Thyroid 18 1095-1103. (doi:10.1089/thy.2008.0090)

Boelen A, Kwakkel J, Chassande O \& Fliers E 2009a Thyroid hormone receptor $\beta$ mediates acute illness-induced alterations in central thyroid hormone metabolism. Journal of Neuroendocrinology 21 465-472. (doi:10.1111/j.1365-2826.2009.01863.x)

Boelen A, Kwakkel J, Wieland CW, St Germain DL, Fliers E \& Hernandez A $2009 b$ Impaired bacterial clearance in type 3 deiodinase-deficient mice infected with Streptococcus pneumoniae. Endocrinology 150 1984-1990. (doi:10.1210/en.2008-1133)

Boelen A, van Beeren M, Vos X, Surovtseva O, Belegri E, Saaltink DJ, Vreugdenhil E, Kalsbeek A, Kwakkel J \& Fliers E 2012 Leptin administration restores the fasting-induced increase of hepatic type 3 deiodinase expression in mice. Thyroid 22 192-199. (doi:10.1089/ thy.2011.0289)

Burger AG, Engler D, Buergi U, Weissel M, Steiger G, Ingbar SH, Rosin RE \& Babior BM 1983 Ether link cleavage is the major pathway of iodothyronine metabolism in the phagocytosing human leukocyte and also occurs in vivo in the rat. Journal of Clinical Investigation 71 935-949. (doi:10.1172/JCI110848)

Burmeister LA, Pachucki J \& St Germain DL 1997 Thyroid hormones inhibit type 2 iodothyronine deiodinase in the rat cerebral cortex by both preand posttranslational mechanisms. Endocrinology 138 5231-5237. (doi:10.1210/endo.138.12.5602)

Caturegli P, Hejazi M, Suzuki K, Dohan O, Carrasco N, Kohn LD \& Rose NR 2000 Hypothyroidism in transgenic mice expressing IFN- $\gamma$ in the thyroid. PNAS 97 1719-1724. (doi:10.1073/pnas.020522597)

Chopra IJ, Huang TS, Boado R, Solomon DH \& Chua Teco GN 1987 Evidence against benefit from replacement doses of thyroid hormones in nonthyroidal illness (NTI): studies using turpentine oil-injected rat. Journal of Endocrinological Investigation 10 559-564. (doi:10.1007/ BF03346994)

Curcio-Morelli C, Zavacki AM, Christofollete M, Gereben B, de Freitas BC, Harney JW, Li Z, Wu G \& Bianco AC 2003 Deubiquitination of type 2 iodothyronine deiodinase by von Hippel-Lindau protein-interacting deubiquitinating enzymes regulates thyroid hormone activation. Journal of Clinical Investigation 112 189-196. (doi:10.1172/JCI18348)

Darras VM, Hume R \& Visser TJ 1999 Regulation of thyroid hormone metabolism during fetal development. Molecular and Cellular Endocrinology 151 37-47. (doi:10.1016/S0303-7207(99)00088-X)

Debaveye Y, Ellger B, Mebis L, Van Herck E, Coopmans W, Darras V \& Van den Berghe G 2005 Tissue deiodinase activity during prolonged critical illness: effects of exogenous thyrotropin-releasing hormone and its combination with growth hormone releasing peptide-2. Endocrinology 146 5604-5611. (doi:10.1210/en.2005-0963)

Debaveye Y, Ellger B, Mebis L, Visser TJ, Darras VM \& Van den Berghe G 2008 Effects of substitution and high-dose thyroid hormone therapy on deiodination, sulfoconjugation, and tissue thyroid hormone levels in prolonged critically ill rabbits. Endocrinology 149 4218-4228. (doi:10.1210/en.2007-1566)

Dentice M, Marsili A, Ambrosio R, Guardiola O, Sibilio A, Paik JH, Minchiotti G, DePinho RA, Fenzi G, Larsen PR et al. 2010 The FoxO3/type 2 deiodinase pathway is required for normal mouse myogenesis and muscle regeneration. Journal of Clinical Investigation 120 4021-4030. (doi:10.1172/JCI43670)

Dentice M, Ambrosio R, Damiano V, Sibilio A, Luongo C, Guardiola O, Yennek S, Zordan P, Minchiotti G, Colao A et al. 2014 Intracellular inactivation of thyroid hormone is a survival mechanism for muscle stem cell proliferation and lineage progression. Cell Metabolism 20 1038-1048. (doi:10.1016/j.cmet.2014.10.009)

Deuss U, Buscema M, Schumacher H \& Winkelmann W 1992 In vitro effects of tumor necrosis factor- $\alpha$ on human thyroid follicular cells. Acta Endocrinologica 127 220-225.

Diano S, Naftolin F, Goglia F \& Horvath TL 1998 Fasting-induced increase in type II iodothyronine deiodinase activity and messenger ribonucleic acid levels is not reversed by thyroxine in the rat hypothalamus. Endocrinology 139 2879-2884. (doi:10.1210/endo.139.6.6062)

Docter R, Krenning EP, de Jong M \& Hennemann G 1993 The sick euthyroid syndrome: changes in thyroid hormone serum parameters and hormone metabolism. Clinical Endocrinology 39 499-518. (doi:10.1111/j.1365-2265.1993.tb02401.x)

Escobar-Morreale HF, Obregon MJ, Hernandez A, Escobar del Rey F \& Morreale de Escobar G 1997 Regulation of iodothyronine deiodinase activity as studied in thyroidectomized rats infused with thyroxine or triiodothyronine. Endocrinology 138 2559-2568. (doi:10.1210/endo. 138.6.5212)

Faber J, Kirkegaard C, Jorgensen B \& Kludt J 1989 The hidden, nonexchangeable pool of 3,5,3'-triiodothyronine and 3,3',5'-triiodothyronine in man: does it exist? Acta Endocrinologica 120 667-671.

Faggioni R, Fantuzzi G, Fuller J, Dinarello CA, Feingold KR \& Grunfeld C 1998 IL-1 $\beta$ mediates leptin induction during inflammation. American Journal of Physiology. Regulatory, Integrative and Comparative Physiology 274 R204-R208. 
Fekete C \& Lechan RM 2007 Negative feedback regulation of hypophysiotropic thyrotropin-releasing hormone (TRH) synthesizing neurons: role of neuronal afferents and type 2 deiodinase. Frontiers in Neuroendocrinology 28 97-114. (doi:10.1016/j.yfrne.2007.04.002)

Fekete C, Gereben B, Doleschall M, Harney JW, Dora JM, Bianco AC, Sarkar S, Liposits Z, Rand W, Emerson C et al. 2004 Lipopolysaccharide induces type 2 iodothyronine deiodinase in the mediobasal hypothalamus: implications for the nonthyroidal illness syndrome. Endocrinology 145 1649-1655. (doi:10.1210/en.2003-1439)

Fekete C, Sarkar S, Christoffolete MA, Emerson CH, Bianco AC \& Lechan RM 2005 Bacterial lipopolysaccharide (LPS)-induced type 2 iodothyronine deiodinase (D2) activation in the mediobasal hypothalamus $(\mathrm{MBH})$ is independent of the LPS-induced fall in serum thyroid hormone levels. Brain Research 1056 97-99. (doi:10.1016/j.brainres. 2005.07.021)

Fekete C, Freitas BC, Zeold A, Wittmann G, Kadar A, Liposits Z, Christoffolete MA, Singru P, Lechan RM, Bianco AC et al. 2007 Expression patterns of WSB-1 and USP-33 underlie cell-specific posttranslational control of type 2 deiodinase in the rat brain. Endocrinology 148 4865-4874. (doi:10.1210/en.2007-0448)

Fliers E, Guldenaar SEF, Wiersinga WM \& Swaab DF 1997 Decreased hypothalamic thyrotropin-releasing hormone gene expression in patients with nonthyroidal illness. Journal of Clinical Endocrinology and Metabolism 82 4032-4036. (doi:10.1210/jcem.82.12.4404)

Freitas BC, Gereben B, Castillo M, Kallo I, Zeold A, Egri P, Liposits Z, Zavacki AM, Maciel RM, Jo S et al. 2010 Paracrine signaling by glial cell-derived triiodothyronine activates neuronal gene expression in the rodent brain and human cells. Journal of Clinical Investigation 120 2206-2217. (doi:10.1172/JCI41977)

Gerard AC, Boucquey M, van den Hove MF \& Colin IM 2006 Expression of TPO and ThOXs in human thyrocytes is downregulated by IL- $1 \alpha / \mathrm{IFN}-\gamma$, an effect partially mediated by nitric oxide. American Journal of Physiology. Endocrinology and Metabolism 291 E242-E253. (doi:10.1152/ ajpendo.00439.2005)

Gereben B, Goncalves C, Harney JW, Larsen PR \& Bianco AC 2000 Selective proteolysis of human type 2 deiodinase: a novel ubiquitin-proteasomal mediated mechanism for regulation of hormone activation. Molecular Endocrinology 14 1697-1708. (doi:10.1210/mend.14.11.0558)

Gereben B, Zeold A, Dentice M, Salvatore D \& Bianco AC 2008 Activation and inactivation of thyroid hormone by deiodinases: local action with general consequences. Cellular and Molecular Life Sciences 65 570-590. (doi:10.1007/s00018-007-7396-0)

Goswami A \& Rosenberg IN 1987 Thioredoxin stimulates enzymatic outer ring monodeiodination of reverse triiodothronine. Endocrinology $\mathbf{1 2 1}$ 1937-1945. (doi:10.1210/endo-121-6-1937)

Gramm HJ, Meinhold H, Voigt K \& Dennhardt R 1989 Diiodotyrosine (DIT): a new marker of leukocyte phagocytic activity in sepsis and severe infections. Progress in Clinical and Biological Research 308 711-713.

van Haasteren GA, van der Meer MJ, Hermus AR, Linkels E, Klootwijk W, Kaptein E, van Toor H, Sweep CG, Visser TJ \& de Greef WJ 1994 Different effects of continuous infusion of interleukin-1 and interleukin-6 on the hypothalamic-hypophysial-thyroid axis. Endocrinology 135 1336-1345. (doi:10.1210/endo.135.4.7925094)

Harel G, Shamoun DS, Kane JP, Magner JA \& Szabo M 1995 Prolonged effects of tumor necrosis factor- $\alpha$ on anterior pituitary hormone release. Peptides 16 641-645. (doi:10.1016/0196-9781(95)00019-G)

Hashimoto H, Igarashi N, Miyawaki T \& Sato T 1995 Effects of tumor necrosis factor- $\alpha$, interleukin- $1 \beta$, and interleukin- 6 on type I iodothyronine $5^{\prime}$-deiodination in rat thyroid cell line, FRTL-5. Journal of Interferon \& Cytokine Research 15 367-375. (doi:10.1089/ jir.1995.15.367)

Heemstra KA, Soeters MR, Fliers E, Serlie MJ, Burggraaf J, van Doorn MB, van der Klaauw AA, Romijn JA, Smit JW, Corssmit EP et al. 2009 Type 2 iodothyronine deiodinase in skeletal muscle: effects of hypothyroidism and fasting. Journal of Clinical Endocrinology and Metabolism 94 2144-2150. (doi:10.1210/jc.2008-2520)

Hermus RM, Sweep CG, van der Meer MJ, Ross HA, Smals AG, Benraad TJ \& Kloppenborg PW 1992 Continuous infusion of interleukin-1 $\beta$ induces a nonthyroidal illness syndrome in the rat. Endocrinology 131 2139-2146. (doi:10.1210/endo.131.5.1425414)

Heuer H, Maier MK, Iden S, Mittag J, Friesema EC, Visser TJ \& Bauer K 2005 The monocarboxylate transporter 8 linked to human psychomotor retardation is highly expressed in thyroid hormone-sensitive neuron populations. Endocrinology 146 1701-1706. (doi:10.1210/en. 2004-1179)

Jakobs TC, Schmutzler C, Meissner J \& Kohrle J 1997 The promoter of the human type I 5'-deiodinase gene - mapping of the transcription start site and identification of a DR +4 thyroid-hormone-responsive element. European Journal of Biochemistry 247 288-297. (doi:10.1111/j. 1432-1033.1997.00288.x)

Janssen R, Zuidwijk M, Muller A, Mulders J, Oudejans CB \& Simonides WS 2013 Cardiac expression of deiodinase type 3 (Dio3) following myocardial infarction is associated with the induction of a pluripotency microRNA signature from the Dlk1-Dio3 genomic region. Endocrinology 154 1973-1978. (doi:10.1210/en.2012-2017)

Kakucska I, Romero LI, Clark BD, Rondeel JM, Qi YP, Alex S, Emerson CH \& Lechan RM 1994 Suppression of thyrotropin-releasing-hormone geneexpression by interleukin-1- $\beta$ in the rat - implications for nonthyroidal illness. Neuroendocrinology 59 129-137. (doi:10.1159/000126649)

Kakucska I, Qi YP \& Lechan RM 1995 Changes in adrenal status affect hypothalamic thyrotropin-releasing-hormone gene-expression in parallel with corticotropin-releasing hormone. Endocrinology 136 2795-2802. (doi:10.1210/endo.136.7.7789304)

Kaptein E, Vanhaasteren GA, Linkels E, Degreef WJ \& Visser TJ 1997 Characterization of iodothyronine sulfotransferase activity in rat liver. Endocrinology 138 5136-5143. (doi:10.1210/endo.138.12.5555)

Klebanoff SJ 2005 Myeloperoxidase: friend and foe. Journal of Leukocyte Biology 77 598-625. (doi:10.1189/jlb.1204697)

Knapp S, Leemans JC, Florquin S, Branger J, Maris NA, Pater J, van Rooijen N \& van der Poll T 2003 Alveolar macrophages have a protective antiinflammatory role during murine pneumococcal pneumonia. American Journal of Respiratory and Critical Care Medicine 167 171-179. (doi:10.1164/rccm.200207-6980C)

Kohrle J 2000 The deiodinase family: selenoenzymes regulating thyroid hormone availability and action. Cellular and Molecular Life Sciences $\mathbf{5 7}$ 1853-1863. (doi:10.1007/PL00000667)

Kung AW, Ma L \& Lau KS 1992 The role of interferon- $\gamma$ in lymphocytic thyroiditis: its functional and pathological effect on human thyrocytes in culture. Clinical and Experimental Immunology 87 261-265. (doi:10. 1111/j.1365-2249.1992.tb02985.x)

Kwakkel J, Wiersinga WM \& Boelen A 2006 Differential involvement of nuclear factor- $\kappa \mathrm{B}$ and activator protein-1 pathways in the interleukin$1 \beta$-mediated decrease of deiodinase type 1 and thyroid hormone receptor $\beta 1$ mRNA. Journal of Endocrinology 189 37-44. (doi:10.1677/ joe.1.06354)

Kwakkel J, Wiersinga WM \& Boelen A 2007 Interleukin-1 $\beta$ modulates endogenous thyroid hormone receptor $\alpha$ gene transcription in liver cells. Journal of Endocrinology 194 257-265. (doi:10.1677/JOE-06-0177)

Kwakkel J, Chassande O, van Beeren HC, Wiersinga WM \& Boelen A 2008 Lacking thyroid hormone receptor $\beta$ gene does not influence alterations in peripheral thyroid hormone metabolism during acute illness. Journal of Endocrinology 197 151-158. (doi:10.1677/ JOE-07-0601)

Kwakkel J, van Beeren HC, Ackermans MT, Platvoet-Ter Schiphorst MC, Fliers E, Wiersinga WM \& Boelen A 2009 Skeletal muscle deiodinase type 2 regulation during illness in mice. Journal of Endocrinology 203 263-270. (doi:10.1677/JOE-09-0118)

Kwakkel J, Chassande O, van Beeren HC, Fliers E, Wiersinga WM \& Boelen A 2010 Thyroid hormone receptor $\{\alpha\}$ modulates lipopolysaccharide-

Published by Bioscientifica Ltd. 
induced changes in peripheral thyroid hormone metabolism. Endocrinology 151 1959-1969. (doi:10.1210/en.2009-1049)

Kwakkel J, Surovtseva OV, de Vries EM, Stap J, Fliers E \& Boelen A 2014 A novel role for the thyroid hormone-activating enzyme type 2 deiodinase in the inflammatory response of macrophages. Endocrinology 155 2725-2734. (doi:10.1210/en.2013-2066)

Lamirand A, Ramauge M, Pierre M \& Courtin F 2011 Bacterial lipopolysaccharide induces type 2 deiodinase in cultured rat astrocytes. Journal of Endocrinology 208 183-192. (doi:10.1677/JOE-10-0218)

Leeper-Woodford SK \& Detmer K 1999 Acute hypoxia increases alveolar macrophage tumor necrosis factor activity and alters NF-kB expression. American Journal of Physiology 276 L909-L916.

Lentsch AB, Czermak BJ, Bless NM \& Ward PA 1998 NF-кB activation during IgG immune complex-induced lung injury: requirements for TNF- $\alpha$ and IL- $1 \beta$ but not complement. American Journal of Pathology 152 1327-1336.

Ma SF, Xie L, Pino-Yanes M, Sammani S, Wade MS, Letsiou E, Siegler J, Wang T, Infusino G, Kittles RA et al. 2011 Type 2 deiodinase and host responses of sepsis and acute lung injury. American Journal of Respiratory Cell and Molecular Biology 45 1203-1211. (doi:10.1165/rcmb.201101790C)

Maia AL, Kim BW, Huang SA, Harney JW \& Larsen PR 2005 Type 2 iodothyronine deiodinase is the major source of plasma $\mathrm{T}_{3}$ in euthyroid humans. Journal of Clinical Investigation 115 2524-2533. (doi:10.1172/ JCI25083)

Marsili A, Ramadan W, Harney JW, Mulcahey M, Castroneves LA, Goemann IM, Wajner SM, Huang SA, Zavacki AM, Maia AL et al. 2010 Type 2 iodothyronine deiodinase levels are higher in slow-twitch than fast-twitch mouse skeletal muscle and are increased in hypothyroidism. Endocrinology 151 5952-5960. (doi:10.1210/en.2010-0631)

Marsili A, Tang D, Harney JW, Singh P, Zavacki AM, Dentice M, Salvatore D \& Larsen PR 2011 Type II iodothyronine deiodinase provides intracellular 3,5,3'-triiodothyronine to normal and regenerating mouse skeletal muscle. American Journal of Physiology. Endocrinology and Metabolism 301 E818-E824. (doi:10.1152/ajpendo.00292.2011)

Mebis L, Langouche L, Visser TJ \& Van den Berghe G 2007 The type II iodothyronine deiodinase is up-regulated in skeletal muscle during prolonged critical illness. Journal of Clinical Endocrinology and Metabolism 92 3330-3333. (doi:10.1210/jc.2007-0510)

Mebis L, Debaveye Y, Ellger B, Derde S, Ververs EJ, Langouche L, Darras VM, Fliers E, Visser TJ \& den Berghe G 2009 Changes in the central component of the hypothalamus-pituitary-thyroid axis in a rabbit model of prolonged critical illness. Critical Care 13 R147. (doi:10.1186/ cc8043)

Meinhold H, Gramm HJ, Meissner W, Zimmermann J, Schwander J, Dennhardt R \& Voigt K 1991 Elevated serum diiodotyrosine (DIT) in severe infections and sepsis: DIT, a possible new marker of leukocyte activity. Journal of Clinical Endocrinology and Metabolism 72 945-953. (doi:10.1210/jcem-72-4-945)

Mol JA \& Visser TJ 1985 Rapid and selective inner ring deiodination of thyroxine sulfate by rat-liver deiodinase. Endocrinology 117 8-12. (doi:10.1210/endo-117-1-8)

Nagaya T, Fujieda M, Otsuka G, Yang JP, Okamoto T \& Seo H 2000 A potential role of activated NF- $\kappa B$ in the pathogenesis of euthyroid sick syndrome. Journal of Clinical Investigation 106 393-402. (doi:10.1172/ JCI7771)

Nagayama Y, Izumi M, Ashizawa K, Kiriyama T, Yokoyama N, Morita S, Ohtakara S, Fukuda T, Eguchi K, Morimoto I et al. 1987 Inhibitory effect of interferon- $\gamma$ on the response of human thyrocytes to thyrotropin (TSH) stimulation: relationship between the response to TSH and the expression of DR antigen. Journal of Clinical Endocrinology and Metabolism 64 949-953. (doi:10.1210/jcem-64-5-949)

Nishikawa T, Yamashita S, Namba H, Usa T, Tominaga T, Kimura H, Izumi M \& Nagataki S 1993 Interferon- $\gamma$ inhibition of human thyrotropin receptor gene expression. Journal of Clinical Endocrinology and Metabolism 77 1084-1089. (doi:10.1210/jcem.77.4.8408457)
Nolte A, Bechtner G, Rafferzeder M \& Gartner R 1994 Interleukin-1 $\beta$ (IL-1 $\beta$ ) binds to intact porcine thyroid follicles, decreases iodide uptake but has no effect on cAMP formation or proliferation. Hormone and Metabolic Research 26 413-418. (doi:10.1055/s-2007-1001720)

Ochs RS 1984 Glutamine metabolism of isolated rat hepatocytes. Evidence for catecholamine activation of $\alpha$-ketoglutarate dehydrogenase. Journal of Biological Chemistry 259 13004-13010.

Ohba K, Yoshioka T \& Muraki T 2001 Identification of two novel splicing variants of human type II iodothyronine deiodinase mRNA. Molecular and Cellular Endocrinology 172 169-175. (doi:10.1016/S03037207(00)00368-3)

Olivares EL, Marassi MP, Fortunato RS, da Silva AC, Costa-e-Sousa RH, Araujo IG, Mattos EC, Masuda MO, Mulcahey MA, Huang SA et al. 2007 Thyroid function disturbance and type 3 iodothyronine deiodinase induction after myocardial infarction in rats a time course study. Endocrinology 148 4786-4792. (doi:10.1210/en.2007-0043)

Oliver KM, Garvey JF, Ng CT, Veale DJ, Fearon U, Cummins EP \& Taylor CT 2009 Hypoxia activates NF-kB-dependent gene expression through the canonical signaling pathway. Antioxidants \& Redox Signaling 11 2057-2064. (doi:10.1089/ars.2008.2400)

Peeters RP, Wouters PJ, Kaptein E, van Toor H, Visser TJ \& Van den Berghe G 2003 Reduced activation and increased inactivation of thyroid hormone in tissues of critically ill patients. Journal of Clinical Endocrinology and Metabolism 88 3202-3211. (doi:10.1210/jc.2002-022013)

Peeters RP, Kester MH, Wouters PJ, Kaptein E, van Toor H, Visser TJ \& Van den Berghe G 2005 Increased thyroxine sulfate levels in critically ill patients as a result of a decreased hepatic type I deiodinase activity. Journal of Clinical Endocrinology and Metabolism 90 6460-6465. (doi:10.1210/jc.2005-0866)

Pekary AE, Berg L, Santini F, Chopra I \& Hershman JM 1994 Cytokines modulate type I iodothyronine deiodinase mRNA levels and enzyme activity in FRTL-5 rat thyroid cells. Molecular and Cellular Endocrinology 101 R31-R35. (doi:10.1016/0303-7207(94)90256-9)

Poth M, Tseng YC \& Wartofsky L 1991 Inhibition of TSH activation of human cultured thyroid cells by tumor necrosis factor: an explanation for decreased thyroid function in systemic illness? Thyroid 1 235-240. (doi:10.1089/thy.1991.1.235)

Rasmussen AK, Bech K, Feldtrasmussen U, Poulsen S, Holten I, Ryberg M, Dinarello CA, Siersbaeknielsen K, Friis T \& Bendtzen K 1988 Interleukin-1 affects the function of cultured human thyroid-cells. Allergy 43 435-441. (doi:10.1111/j.1398-9995.1988.tb00915.x)

Rasmussen AK, Kayser L, Bech K, Feldtrasmussen U, Perrild H \& Bendtzen K 1991 Influence of interleukin- 6 on the function of secondary cultures of human thyrocytes. Acta Endocrinologica 124 577-582.

Rasmussen AK, Kayser L, Feldt-Rasmussen U \& Bendtzen K 1994 Influence of tumour necrosis factor- $\alpha$, tumour necrosis factor- $\beta$ and interferon- $\gamma$, separately and added together with interleukin- $1 \beta$, on the function of cultured human thyroid cells. Journal of Endocrinology 143 359-365. (doi:10.1677/joe.0.1430359)

Rodriguez-Perez A, Palos-Paz F, Kaptein E, Visser TJ, Dominguez-Gerpe L, Alvarez-Escudero J \& Lado-Abeal J 2008 Identification of molecular mechanisms related to nonthyroidal illness syndrome in skeletal muscle and adipose tissue from patients with septic shock. Clinical Endocrinology 68 821-827. (doi:10.1111/j.1365-2265.2007.03102.x)

Sagar GD, Gereben B, Callebaut I, Mornon JP, Zeold A, da Silva WS, Luongo C, Dentice M, Tente SM, Freitas BC et al. 2007 Ubiquitinationinduced conformational change within the deiodinase dimer is a switch regulating enzyme activity. Molecular and Cellular Biology 27 4774-4783. (doi:10.1128/MCB.00283-07)

Sanchez E, Singru PS, Wittmann G, Nouriel SS, Barrett P, Fekete C \& Lechan RM 2010 Contribution of TNF- $\alpha$ and nuclear factor- $-\mathrm{B}$ signaling to type 2 iodothyronine deiodinase activation in the mediobasal hypothalamus after lipopolysaccharide administration. Endocrinology 151 3827-3835. (doi:10.1210/en.2010-0279) 
Sato K, Satoh T, Shizume K, Ozawa M, Han DC, Imamura H, Tsushima T, Demura H, Kanaji Y, Ito Y et al. 1990 Inhibition of ${ }^{125}$ I organification and thyroid hormone release by interleukin-1, tumor necrosis factor- $\alpha$, and interferon- $\gamma$ in human thyrocytes in suspension culture. Journal of Clinical Endocrinology and Metabolism 70 1735-1743. (doi:10.1210/ jcem-70-6-1735)

Schneider MJ, Fiering SN, Pallud SE, Parlow AF, St Germain DL \& Galton VA 2001 Targeted disruption of the type 2 selenodeiodinase gene (DIO2) results in a phenotype of pituitary resistance to $\mathrm{T}_{4}$. Molecular Endocrinology 15 2137-2148. (doi:10.1210/mend.15.12.0740)

Simonides WS, Mulcahey MA, Redout EM, Muller A, Zuidwijk MJ, Visser TJ, Wassen FW, Crescenzi A, Da-Silva WS, Harney J et al. 2008 Hypoxiainducible factor induces local thyroid hormone inactivation during hypoxic-ischemic disease in rats. Journal of Clinical Investigation 118 975-983. (doi:10.1172/JCI32824)

St Germain DL, Galton VA \& Hernandez A 2009 Minireview: Defining the roles of the iodothyronine deiodinases: current concepts and challenges. Endocrinology 150 1097-1107. (doi:10.1210/en.2008-1588)

Sugiyama D, Kusuhara H, Taniguchi H, Ishikawa S, Nozaki Y, Aburatani H \& Sugiyama Y 2003 Functional characterization of rat brain-specific organic anion transporter (Oatp14) at the blood-brain barrier: high affinity transporter for thyroxine. Journal of Biological Chemistry $\mathbf{2 7 8}$ 43489-43495. (doi:10.1074/jbc.M306933200)

Tang KT, Braverman LE \& DeVito WJ 1995 Tumor necrosis factor- $\alpha$ and interferon- $\gamma$ modulate gene expression of type I 5 '-deiodinase, thyroid peroxidase, and thyroglobulin in FRTL-5 rat thyroid cells. Endocrinology 136 881-888. (doi:10.1210/endo.136.3.7867596)

Taurog A, Briggs FN \& Chaikoff IL 1952 I $^{131}$-labeled 1-thyroxine. II. Nature of the excretion product in bile. Journal of Biological Chemistry 194 655-668.

Tominaga T, Yamashita S, Nagayama Y, Morita S, Yokoyama N, Izumi M \& Nagataki S 1991 Interleukin-6 inhibits human thyroid peroxidase geneexpression. Acta Endocrinologica 124 290-294.

Toyoda N, Zavacki AM, Maia AL, Harney JW \& Larsen PR 1995 A novel retinoid $\mathrm{X}$ receptor-independent thyroid hormone response element is present in the human type 1 deiodinase gene. Molecular and Cellular Biology 15 5100-5112.

Tukey RH \& Strassburg CP 2001 Genetic multiplicity of the human UDPglucuronosyltransferases and regulation in the gastrointestinal tract. Molecular Pharmacology 59 405-414.

Visser TJ 1994 Role of sulfation in thyroid-hormone metabolism. Chemico-Biological Interactions 92 293-303. (doi:10.1016/00092797(94)90071-X)

Visser TJ, Kaptein E, Glatt H, Bartsch I, Hagen M \& Coughtrie MW 1998 Characterization of thyroid hormone sulfotransferases. Chemico-Biological Interactions 109 279-291. (doi:10.1016/S0009-2797(97)00139-7)

Visser WE, Friesema EC \& Visser TJ 2011 Minireview: Thyroid hormone transporters: the knowns and the unknowns. Molecular Endocrinology 25 1-14. (doi:10.1210/me.2010-0095) de Vries EM, Kwakkel J, Eggels L, Kalsbeek A, Barrett P, Fliers E \& Boelen A $2014 a \mathrm{NF \kappa B}$ signaling is essential for the lipopolysaccharide-induced increase of type 2 deiodinase in tanycytes. Endocrinology $\mathbf{1 5 5}$ 2000-2008. (doi:10.1210/en.2013-2018)

de Vries EM, Eggels L, van Beeren HC, Ackermans MT, Kalsbeek A, Fliers E \& Boelen A 2014b Fasting-induced changes in hepatic thyroid hormone metabolism in male rats are independent of autonomic nervous input to the liver. Endocrinology 155 5033-5041. (doi:10.1210/en.2014-1608)

Wajner SM, Goemann IM, Bueno AL, Larsen PR \& Maia AL 2011 IL-6 promotes nonthyroidal illness syndrome by blocking thyroxine activation while promoting thyroid hormone inactivation in human cells. Journal of Clinical Investigation 121 1834-1845. (doi:10.1172/ JCI44678)

Wang G, Huang X, Li Y, Guo K, Ning P \& Zhang Y 2013 PARP-1 inhibitor, DPQ, attenuates LPS-induced acute lung injury through inhibiting NF-kB-mediated inflammatory response. PLoS ONE 8 e79757. (doi:10.1371/journal.pone.0079757)

Wassen FW, Moerings EP, Van Toor H, De Vrey EA, Hennemann G \& Everts ME 1996 Effects of interleukin-1 $\beta$ on thyrotropin secretion and thyroid hormone uptake in cultured rat anterior pituitary cells. Endocrinology 137 1591-1598. (doi:10.1210/endo.137.5.8612490)

Wassen FW, Schiel AE, Kuiper GG, Kaptein E, Bakker O, Visser TJ \& Simonides WS 2002 Induction of thyroid hormone-degrading deiodinase in cardiac hypertrophy and failure. Endocrinology 143 2812-2815. (doi:10.1210/endo.143.7.8985)

Weekers F, Van Herck E, Coopmans W, Michalaki M, Bowers CY, Veldhuis JD \& Van den Berghe G 2002 A novel in vivo rabbit model of hypercatabolic critical illness reveals a biphasic neuroendocrine stress response. Endocrinology 143 764-774. (doi:10.1210/endo.143.3.8664)

Werneck de Castro JP, Fonseca TL, Ueta CB, McAninch EA, Abdalla S, Wittmann G, Lechan RM, Gereben B \& Bianco AC 2015 Differences in hypothalamic type 2 deiodinase ubiquitination explain localized sensitivity to thyroxine. Journal of Clinical Investigation 125 769-781. (doi:10.1172/JCI77588)

Yamashita S, Kimura H, Ashizawa K, Nagayama Y, Hirayu H, Izumi M \& Nagataki S 1989 Interleukin-1 inhibits thyrotrophin-induced human thyroglobulin gene expression. Journal of Endocrinology 122 177-183. (doi:10.1677/joe.0.1220177)

Yu JC \& Koenig RJ 2000 Regulation of hepatocyte thyroxine 5'-deiodinase by $\mathrm{T}_{3}$ and nuclear receptor coactivators as a model of the sick euthyroid syndrome. Journal of Biological Chemistry 275 38296-38301. (doi:10. 1074/jbc.M004866200)

Yu J \& Koenig RJ 2006 Induction of type 1 iodothyronine deiodinase to prevent the nonthyroidal illness syndrome in mice. Endocrinology 147 3580-3585. (doi:10.1210/en.2005-1443)

Zeold A, Doleschall M, Haffner MC, Capelo LP, Menyhert J, Liposits Z, da Silva WS, Bianco AC, Kacskovics I, Fekete C et al. 2006 Characterization of the nuclear factor- $\mathrm{\kappa B}$ responsiveness of the human dio2 gene. Endocrinology 147 4419-4429. (doi:10.1210/en.2005-1608)

Received in final form 4 May 2015

Accepted 13 May 2015

Accepted Preprint published online 13 May 2015 http://joe.endocrinology-journals.org

DOI: 10.1530/JOE-15-0133
(C) 2015 Society for Endocrinology Printed in Great Britain
Published by Bioscientifica Ltd. 